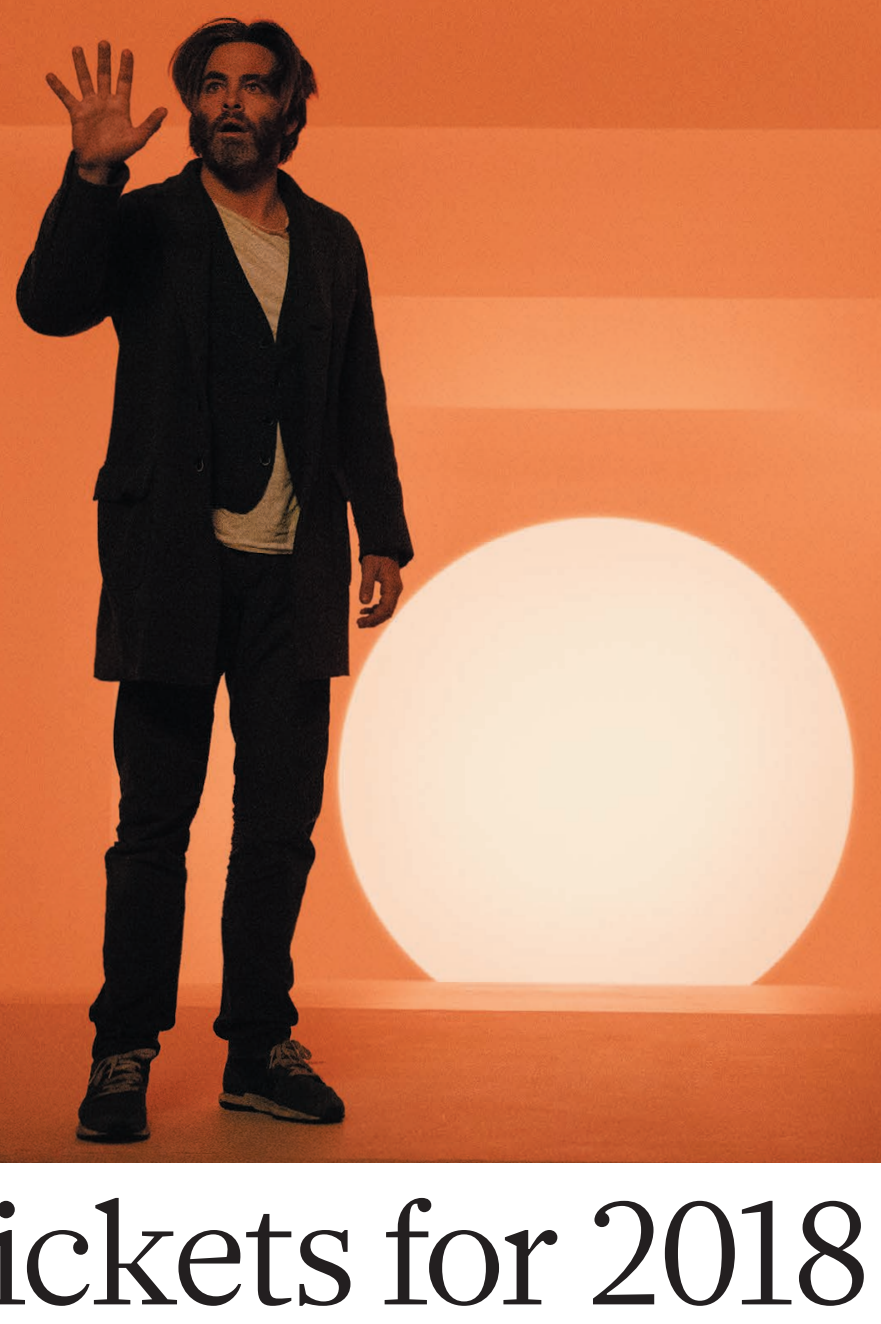

NASA turns 60, Antarctic dinosaurs lumber into view, fruit waste transforms fashion and Madeleine L'Engle's sci-fi classic A Wrinkle in Time hits the screen. Around the world, museums and galleries will explore everything from our relationship with time to the brain's beauty, Fatimid science and the wonder of graphene. Nicola Jones reports.

\section{Mad Minds}

Victor Hugo's Houses, Paris

Until 18 March

In the nineteenth century, psychiatry was evolving. While patients in asylums such as London's Bethlem Hospital (nicknamed Bedlam) suffered indignities and abuse, a new movement encouraged ethical treatments. Instead of chains and isolation, it encouraged freedom of movement and self-expression. Practitioners such as Scottish physician William Browne started to pay closer attention to the art and writing of people with mental illnesses. And psychiatrists became the first collectors and critics of these works, which some have seen as representing artistic drive at its rawest. This show includes pieces amassed by Browne, who pioneered ideas of art therapy at Crichton Royal Hospital in Dumfries, UK, alongside similar collections from Germany and Switzerland.

\section{Painted Surfaces}

Iziko South African National Gallery, Cape Town Until 1 April 2018

A chance to peer beneath the surface of paintings by some of South Africa's greatest artists, including Stanley Pinker,
Irma Stern, Frederick I'Ons and George Pemba, awaits at this exhibition. The results of a three-year collaboration by institutions including the University of Cape Town and the University of the Western Cape, it explores the artists' techniques and the histories of their works through infrared photography, ultraviolet light, X-ray imaging and microscopic analysis. Infrared images, for example, reveal that the tin support of l'Ons's Krantzdrift: Landscape with Cattle was an enamel shop sign advertising Peek Frean biscuits, which helped to date the work to the late nineteenth century. 
Wonder Materials - Graphene and Beyond Hong Kong Science Museum Until 18 April

Graphene - sheets of carbon one-millionth the thickness of a human hair and 200 times as strong as steel — was known to exist from the 1940s, but wasn't isolated until 2004. That year, physicists Andre Geim and Konstantin Novoselov at the University of Manchester, UK, managed to separate a flake of graphene one atom thick from a lump of graphite using sticky tape (six years later, they won the Nobel Prize in Physics). This highly useful material is now making its mark in industry, with applications in everything from speciality batteries to tennis rackets. Along with its discovery and commercial applications, this exhibition focuses on the material's possible future.

\section{Time Unwrapped}

King's Place, London

6 January - 31 December

This year-long series of more than 50 musical and spoken-word events explores humanity's relationship with time. Kicking off with a talk on timekeeping by David Rooney, keeper of technologies and engineering at London's Science Museum, the series meanders through an eclectic mix of lectures, Bach cantatas, jazz and folk concerts. Cosmologist Malcolm Longair and music critic Tom Service will ponder musical revolutions of the early twentieth century that paralleled Albert Einstein's development of relative time. The line-up also includes experimental physicist Helen Gleeson, who produced the first graphene-based liquid-crystal device; a dramatic recreation of Douglas Adams's novel Dirk Gently's Holistic Detective Agency (William Heinemann, 1987) by actor Geoffrey McGivern; a "human clock" by Hang player and percussionist Manu Delago and others; and a collage by pianist Alasdair Beatson that melds music by Beethoven with the nocturnal sounds of insects.

\section{The Beautiful Brain: The Drawings of}

\section{Santiago Ramón y Cajal}

Grey Art Gallery, New York City

9 January-31 March

Spanish pathologist and Nobel laureate Santiago Ramón y Cajal was a founder of modern neuroscience and an accomplished artist. His dissections and drawings of the human brain in the late nineteenth century provided definitive evidence that the nervous system is made up of discrete cells, including neurons. Ramón y Cajal also discovered a new type of cell, later named after him, amid neurons in the gut. Some 80 of his drawings are in this touring show, which opened at the Weisman Art Museum in Minneapolis,
Minnesota, and will move to the MIT Museum in Cambridge, Massachusetts, in May.

\section{The World of the Fatimids}

Aga Khan Museum, Toronto, Canada

10 March - 2 July

The educational, scientific and artistic legacy of the Fatimids, an Arab dynasty that ruled over swathes of North Africa in the tenth and eleventh centuries AD, features in this sumptuous show. In Cairo, the Fatimids founded one of the world's oldest degreegranting educational institutions - Al-Azhar University - in 970, as well as one of the era's greatest libraries. And their rule advanced science: the pioneer of optics Ibn al-Haytham, for example, lived in Cairo under the caliphate. The exhibition features marble reliefs from Cairo's Museum of Islamic Art, masterpieces in metal, and ceramic lustreware, a Fatimid innovation. Drone videography and virtual-reality films provide a peek at what the Egyptian capital might have looked like a millennium ago.

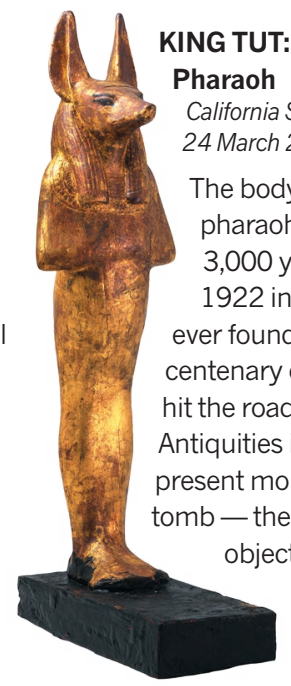

KING TUT: Treasures of the Golden Pharaoh

California Science Center, Los Angeles 4 March 2018 - January 2019

The body of Tutankhamun, the childpharaoh who ruled Egypt more than 3,000 years ago, was discovered in 1922 in the most complete royal tomb ever found in the region. As we near the centenary of that find, Tut's belongings hit the road. The Egyptian Ministry of Antiquities is working with partners to present more than 150 artefacts from the - the largest assembly of original objects ever displayed outside Egypt. (Previous tours, including the 1970s Treasures of Tutankhamun exhibition that drew more than 8 million

visitors to its US sites alone, featured about 50.) This year's show includes a life-size wooden statue of Tutankhamun, a gilded ceremonial bed, a statue of the god Duamutef (pictured) and a jewelled coffinette that held the pharaoh's liver. His famous death mask and mummified body remain in Egypt. The exhibition will move on to Europe after its Los Angeles premiere.

\section{Fashioned from Nature} Victoria and Albert Museum, London 21 April 2018 - 27 January 2019

'Fashion victim' will gain a whole new meaning at this show. For centuries, nature has fallen prey to fashion frenzies. In the Victorian era, for example, birds' body parts were used to make jewellery and trim hats; an 1875 pair of earrings made from the taxidermied heads of honeycreepers (pictured) will be

\section{INA CINEMA NEARYOU...}

Alongside the usual offerings of superhero sequels and Star Wars flicks, 2018 brings a handful of hotly anticipated science-tinged films, from fantasy to nearly-non-fiction.

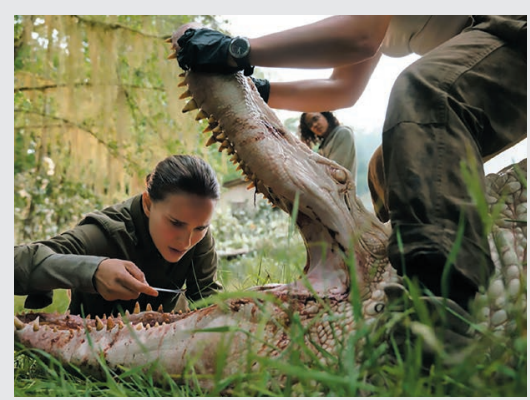

Annihilation From Alex Garland, writerdirector of Ex Machina (2015), comes the story of a biologist (Natalie Portman, pictured), an anthropologist, a psychologist and a surveyor on an expedition into Area X. What they find in this bizarre, alieninfluenced environmental disaster zone is unexpected. US release: 23 February.

A Wrinkle in Time This adaptation of Madeleine L'Engle's classic 1963 sci-fi story, directed by Ava DuVernay, features a star-studded cast that includes Oprah Winfrey, Reese Witherspoon and Chris Pine. Learning that her astrophysicist father is held captive on a distant planet, youthful heroine Meg Murry works with family and a band of unusual friends to save him. US release: 9 March.

Ready Player One Steven Spielberg directs the film of Ernest Cline's 2011 novel. In a dystopian 2040s, people escape overpopulated slums by living, studying and working in a virtual reality, the OASIS. When its quirky creator dies, he leaves behind a treasure hunt for his fortune - and a pack of teenagers aim to beat big business to the prize. US release: 30 March.

First Man NASA's mission to land a man on the Moon gets the Hollywood treatment, with Ryan Gosling as Neil Armstrong. The rights to the book were bought in 2003, but filming - directed by Damien Chazelle, who worked with Gosling on 2016's La La Land — began only after Armstrong's death in 2012. US release: 12 October. 


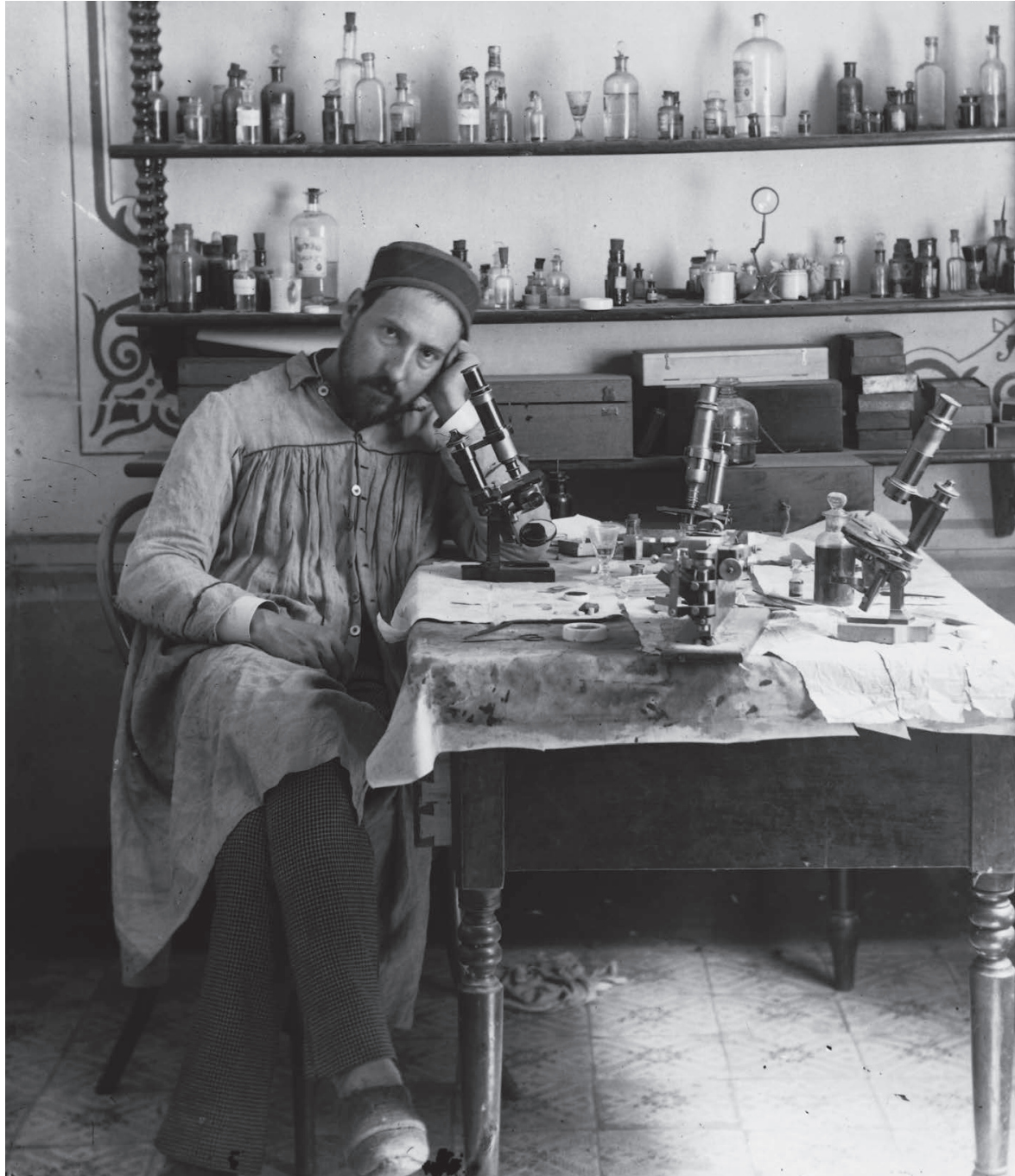

Neuroscience pioneer and artist Santiago Ramón y Cajal is the subject of a touring exhibition.

on display. The exhibition will chart the use of natural materials over 400 years, from silk, wool and cotton to whalebone and turtle shell. More environmentally friendly modern materials will feature, too: clothes crafted from recycled plastic bottles or the fibrous remains of juiced oranges; a dress grown from plant roots by artist Diana Scherer; and a leather substitute created from wineindustry grape waste. If that doesn't wow you, there's a gown of bioluminescent, genetically engineered silk.

\section{Teeth}

Wellcome Collection, London

17 May - 19 September

How did dentistry evolve from fairground entertainment in the early eighteenth century to today's highly skilled profession? This exhibition traces the medical and scientific history of oral hygiene and dentistry, as well as their evolving association with beauty and wealth. It will draw on Wellcome Collection images, objects and artworks, which include documents on how William Shakespeare cleaned his teeth, mercury poisoning from early fillings and the "means of correcting and purifying a tainted or unpleasant breath" in the nineteenth century. A terrifying scanning electron microscope image of a decayed tooth may also feature.

John F. Kennedy Center for the Performing Arts, Washington $D C$

1 June - 2 June

On 29 July 1958, US president Dwight Eisenhower signed the act that gave birth to NASA. In celebration of the agency's 60th birthday, the US National Symphony Orchestra will play music to a backdrop of images from the Hubble Space Telescope, the International Space Station, the Curiosity rover on Mars, and famous sci-fi films and television programmes. Come to hear spaceinspired musical selections, including favourites from Star Trek, and a new

\section{NSO Pops: Space, the Next Frontier} Wars and Star commission by composer Michael Giacchino (winner of a 2010 Academy Award for his score of the animated feature Up).

\section{Antarctic Dinosaurs}

Field Museum, Chicago, Illinois

15 June 2018 - 6 January 2019

Some 200 million years ago, dinosaurs roamed a lushly forested Antarctica, which was then part of a supercontinent that included what are now Africa and South America. In collaboration with the Natural History Museum of Utah in Salt Lake City and other institutions, this travelling exhibition spotlights the continent's Mesozoic landscape, as well as current logistical challenges of doing science in a harsh climate. Dozens of fossils and specimens will be on display, spanning modern plants to extinct animals that lived on the vast landmass before the dinosaurs. The show includes remains and replicas of the first and largest Antarctic dinosaurs discovered: the 7-metre-long Cryolophosaurus; Glacialisaurus; and two juvenile prosauropods. After opening at the Field Museum, it will travel to California, Utah and elsewhere.

\section{Catastrophe and the Power of Art}

Mori Art Museum, Tokyo

6 October 2018 - 20 January 2019

The human ability to bounce back following disasters - whether the global financial crisis of 2008 or the earthquake and tsunami that hit Japan in 2011 — is the focus of this show. The collection spans both personal responses to catastrophe and examinations of wider associated social problems, such as the dream of unrestricted economic growth and the hubris of humanity's urge to control nature. The exhibits will include works by Japanese photographer Naoya Hatakeyama and New York-based hacktivists Eva and Franco Mattes.

\section{Audubon's Birds of America}

New-York Historical Society Museum and Library Ongoing

In 1820, US naturalist John James Audubon declared his intention of depicting every bird in North America. Arranging specimens in lifelike poses using wires and threads, he painted them in watercolour and life-size. His masterpiece The Birds of America (1827-38) contains 435 illustrations (pictured, the wild turkey, Meleagris gallopavo) and introduced 25 new species; it deeply influenced naturalists such as Charles Darwin, who referred to Audubon's work in his 1859 On the Origin of Species. This exhibition features all the original paintings - also available online (see go.nature.com/2c7i3i1) alongside plates used for the book. 